\title{
Recovering Hannah Arendt: How and Why?
}

BERNSTEIN R. J. (2018) WHY READ HANNAH ARENDT NOW? CAMBRIDGE: POLITY PRESS. 124 P. ISBN: 978-

$1-509-52859-2$

\author{
Anastasia Kalk \\ PhD Student, Department of Politics, New School for Social Research \\ Program Associate, Transregional Center for Democratic Studies, New School \\ Address: 6 East 16th Street, New York City, New York, USA 100003 \\ E-mail: akalk@newschool.edu
}

Hannah Arendt taught her last courses on revolution, totalitarianism, and democratic theory at the New School for Social Research from 1967 until her death in 1975. Since that time, the New School has carefully preserved Arendt's legacy and has established the Hannah Arendt Center in 200o, i.e., a vast collection of her articles, letters, memoirs, and books. This unique archive is easily accessible today for all scholars interested in Arendt's personal biography and philosophical ideas. It was the philosopher Richard Bernstein who made this center possible and who, like other professors at the New School, greatly contributed to Hannah Arendt's scholarship in the United States and abroad. Bernstein has written multiple books and papers in which he discusses Arendt's ideas and moves her arguments forward. Although while generally promoting Arendtian political thought, Bernstein puts certain elements of her philosophy into question. He criticizes, for example, her famous but severe distinction between the social and political spheres. ${ }^{1}$ In the fall of 2016 when Trump was newly elected as president of the United States, Bernstein was teaching a course on Arendt's politics and philosophy. His new book, Why Read Hannah Arendt Now?, largely echoes this class.

As in his course, Bernstein's book gives a brief but quite dense introduction to Arendt's political philosophy. There is seemingly no single topic or concept that this small book does not cover. Bernstein begins his text by describing Arendt's articles on refugees that she published after moving to New York City in 1941, and then goes on to summarize key arguments of all later major Arendtian works, including The Origins of Totalitarianism, The Human Condition, Between Past and Future, Eichmann in Jerusalem, On Revolution, Men in Dark Times, On Violence, Crises of the Republic, and, finally, The Life of the Mind. The author structures his book around a set of political issues that, as he puts it, Arendt touches on in almost every paper she has ever written. What exactly are these burning

(C) Anastasia Kalk, 2018

(c) Centre for Fundamental Sociology, 2018

DOI: $10.17323 / 1728-192 \mathrm{X}-2018-4-175-180$

1. Bernstein R. J. (1986) Rethinking the Social and the Political. Philosophical Profiles, Philadelphia: University of Pennsylvania Press, pp. 238-259. 
issues? According to Bernstein, during her entire academic life in the US, Arendt had been always concerned about political refugees, Zionism, the Jewish nation-state, racism and segregation, the banality of evil, the lack of public freedom and plurality, the high levels of political violence, and, last but not least, the legacies of the American and French Revolutions. Throughout the course of this book, Bernstein argues that "all the problems that Arendt highlights ... continue to plague us - indeed, they have been intensified and exacerbated" (p. 20). Arendt's positions regarding all of the dangerous political tendencies (as they are presented in Bernstein's book) will be revealed in what follows below.

For Arendt, every human thought and philosophical system derives from one's lived experience. Arendtian philosophy, in particular, had been born out of a story of a German-Jewish refugee who escaped Nazi Germany. Arendt's political thought insightfully reflected her social experience. Being a regular columnist for a German-Jewish newspaper and a member of several Jewish associations, Arendt often wrote, for instance, about other German immigrants like herself. As well as losing their former citizenship, German-Jewish refugees, Arendt insisted, lost their community. She argued that 2oth century refugees did not feel fully included in the states that welcomed them, whether it was France or the USA. In most cases, immigrants strived hard to become "ideal" loyal and passive citizens of their new states and were deeply scared of criticizing new governments. In other words, refugees felt unable to engage in public politics, a fact that was, according to Arendt, a symptom of a deep political crisis. The Jewish migrants in Paris and New York with whom she worked with could not exercise their "right to have rights" or the inalienable human right "to belong to a community ... where individuals can express and share opinions and where one can act collectively with fellow human beings" (p. 28). Instead of actively participating in politics, they passively submitted to the state leaders. While refusing to resist, refugees refuse to act politically and collectively and, if using Arendtian language, turned "into something that is not human" (p. 34).

In the first two chapters of the book, Bernstein notes that "there appears to be no end in sight to the increase in the numbers and categories of refugees" in contemporary societies (p. 15), and that "political events add ever new masses of stateless persons and refugees" (p. 20). So, the "refugee-question" still exists today. The question did not evaporate from the world; therefore, the author concludes that Arendt's observations and worries on migration remain highly relevant for us today. Although Bernstein remarkably articulates Arendt's thoughts on refugees, he does not explain how exactly one can link her comments to the politics of the 2010s. Why should we pay attention to growing migration levels on the planet? Is it because migrants in the 2010 s are as politically passive as the French and American Jewish immigrants from the 1940s? Bernstein does not refer to any particular refugee group, or explain why the growth of migration constitutes a dangerous political tendency. In general, he does not clarify what and whom he means when talking about "contemporary refugees" or "contemporary societies." In this regard, his main statement about the especial actuality of Arendt's works for today's world sounds rather groundless. What events, groups, countries, and historical periods does Bernstein have in mind when discussing the "contemporary world" we are living in? What is that politi- 
cal "now" he wants to bring Arendt back into? These two questions re-appear through the book, moving from one chapter to another.

The next three chapters disclose Arendt's analysis of the Jewish-Arab conflict, race segregation in American schools, and the Eichmann trial. For a brief period of time, Arendt was attracted to the Zionist movement. She considered Zionists as the only active force opposing Hitler and the Nazis in the 1930s. However, in the 1940s, when the Zionists introduced their plans to establish a Jewish state, Arendt strongly objected to that program. The Zionists completely disregarded the lives and opinions of the Arabs, i.e., the majority of people living in Palestine. Arendt, hence, stood up against Zionism, defending the idea of a federated "Jewish homeland . . . a place where Jews would learn to live with Arabs in a joint community, where all citizens would have equal rights" (p. 42). According to Bernstein, this severe conflict was essential for Arendt's later ideas about politics and public freedom (as the realm for plural opinions and open public debates). At the end of the chapter, Bernstein reminds the readers that the Israeli-Palestinian conflict has been unresolved since the 1940's, and that Arendt was absolutely right predicting the constant state of exception in Palestine. In this case, no one listened to her. Still, Arendt was not always right. Sometimes her sharp political commentaries could be quite reactionary. Arendt, for instance, opposed the attempts to end race-based school segregation in the US in the late 1950s. She claimed that the government had no right to interfere into the "private" realm of the American educational system: "She even suggested that Negro (black) parents were using their children to fight adult political battles" (p. 50). For Arendt, racial segregation always seemed to be a social rather than political question. Bernstein makes an attempt to elucidate some anti-racist elements of Arendtian philosophy. I do not think, however, that his defense of Arendt against accusations of racism ends up being convincing.

Arendt became a widely-known philosopher primarily for her articles in The New Yorker in which she discussed the Eichmann trial in 1963. With these articles, she got involved in a very public scandal. Many of her friends and colleagues turned away from her after the publication. Some readers thought that Arendt justified Eichman's actions and even sympathized with him. Her main point was, in fact, very simple. The Nazi leader was far from being an extraordinary monster, sadist, or psychopath. On the contrary, the man was as ordinary, diligent, submissive, and banal as many other individuals who supported and created Nazism. He simply followed the rules he was given, and never seemed to question any of them. Bernstein himself generally agrees with Arendt's concept of "the banality of evil," although he does not believe that her description of Eichmann was entirely correct. In a similar manner with the initial chapters, Bernstein concludes this one by stating that Arendt's "idea of the banality of evil is still relevant today because we need to face up to the fact that one does not have to be a monster to commit horrendous evil deeds" (p. 67). Whom and what does he imply as the embodiments of banal evil in the contemporary world? The answers to these questions are again far from being lucid.

After describing Arendt's views on Zionism, racism, and Nazism, Bernstein turns to a discussion about the philosophical system she developed in her later works. Chapters 7 
and 8 are central for Bernstein's book. In these two chapters, Bernstein defines the fundamental Arendtian network of concepts, talking about such categories as politics, plurality, freedom, spontaneity, revolution, natality, power, and action. There is no need, probably, to restate Bernstein's definitions of all of the terms or to summarize the core arguments of Arendt's books, Human Condition and On Revolution. It is worth mentioning here that Bernstein reconstructs Arendt's philosophical framework with great accuracy and precision. He emphasizes that politics, for Arendt, is the name for a collective action directed towards creating something new in a given world. In her works, Arendt proposes a very "narrow" and unique understanding of politics, calling "political" as only the moments when a majority of people comes together to establish a new set of political rules. For her, the term politics refers, in other words, to some privileged situations in which the people exercise their collective power to constitute a new society. It is very important to note here that Arendtian "politics" is a horizontal concept. Unlike other political thinkers, she consistently refused to call domination, violence, command, and obedience "political" relations.

In Chapter 8 (“The American Revolution and the Revolutionary Spirit”), Bernstein repeats his main question of Why Read Hannah Arendt Now? Here, he finally formulates his distinct answer to it. The author argues that it is only Arendtian political philosophy that can provide us today "a source of inspiration for political action" that is so desperately needed in contemporary melancholic and cynical times. It is hard not to agree with him on that point. Like previous chapters, however, this one too lacks important references to existing political movements and events. Nevertheless, using Arendt's ideas and texts, Bernstein aptly identifies the key problem of all democratic protests that have emerged in the 200os-2010s, both in the US and outside. Contrary to popular struggles that led to the American, French and even the October Revolutions, ${ }^{2}$ contemporary movements (like Occupy Wall Street, for example) do not follow any positive project. Their participants tend to give up the idea of constituting another social order. Such movements appear to be merely negative. Therefore, they could be hardly called political in the Arendtian sense of the term. Bernstein dates the last emergence of constitutive politics back to the Polish labour union Solidarność. ${ }^{3}$ Arendtian political philosophy, as Bernstein points out, could help us realize that constitutive revolutionary action is possible today, even in the United States, regardless of multiple structural obstacles. Arendt is the rare philosopher who was certain that the capacity "to act in concert, to initiate, to begin, to strive to make freedom a worldly reality" is deeply rooted in human nature (p. 121). Hence, this revolutionary capacity could never be totally suppressed.

To sum up, Why Read Hannah Arendt Now? is a valuable introductory book about Arendt's philosophy. Its author not only summarizes Arendt's key points, but, more importantly, conveys her unique and affirmative writing style, i.e., the one she became famous for. Bernstein does not impose his thoughts on the German-Jewish philosopher;

\footnotetext{
2. The one that Arendt especially did not like.

3. He notes that the movement could once turn from a mass anti-bureaucratic resistance to a powerful collective force shaping Polish political decisions in the late 1980s - early 199os.
} 
rather, he carefully reveals what Arendt tried to communicate through her multiple papers. Bernstein focuses on the ideas Arendt advocated without distorting them. He really cares about these ideas, praising and leaving them intact. This theoretical "care" could be considered as one of the strongest elements of Bernstein's review. The other very strong element of the book is its effort to present Arendt as a coherent and systematic thinker. Quite often, Arendtian thought is divided by interpreters into journalistic and philosophic parts, between short essays and some "serious" books. In this text, Bernstein proves that such classifications are wrong or, at least, not productive. He argues that Arendt's personal and journalistic reflections fueled her philosophy. These two things are inseparable from each other. To a great extent, Arendtian thought had been developed through reflections on her biography and responses to those political events she had lived through during the 1930s-1960s. In other words, her social experience rather than some Ancient academic training that, as Bernstein highlights, was the real driving force for her theories of politics, democracy, and revolution.

Bernstein's recovery of Arendt's thought, however, raises two important questions. First, how could one connect Arendt's thoughts from the 1930s-1960s to the present political moment? What concepts could be useful and insightful for a political analysis of the 2010s? As already mentioned, Bernstein does not seem to give a detailed answer to these questions that he himself poses in the book. Why Read Hannah Arendt Now? is detached from current political events, mobilizations, and discussions in the United States, Latin America, Europe or Russia. It drops some hints about contemporary dark political times, though avoiding a discussion of the signs and examples of such darkness. ${ }^{4}$ Unlike Arendt, Bernstein almost completely excludes commentaries of particular events, figures, or movements from his writing. Although he does not give an example of an Arendt-like political analysis of the 2010 s himself, in a sense, the book pushes students to engage in such analyses.

The second important question the book leaves open is the question of how to situate Arendt's particular ideas within the larger context of political thought. Is it possible to place Arendt within the history of philosophy? Following Arendt's self-description, Bernstein portrays her as an isolated intellectual figure. He enforces her popular image as a female outsider of the academic world, i.e., one who consciously and consistently refused calling herself a philosopher until her death. Bernstein states that Arendt could not be inscribed to any philosophical tradition and that she remained independent from the philosophical schools and trends of her time. While it is certainly true that Arendt, as she often emphasized in her public speeches, was excluded from the professional philosophical community, ${ }^{5}$ it seems to be a big mistake to interpret her works in isolation from other thinkers both preceding her and inspired by her. Although Arendt, in fact, did not

4. Why exactly do we live in dangerous, hopeless, and totalitarian political times? Women's Marches, International Women's Strikes, Teachers' Strikes, new and strong Socialist wave within the US Democratic Party, all these extraordinary events increasingly undermine the dark vision of the present.

5. See, for example, Arendt H. (2003) Prologue. Responsibility and Judgement, New York: Schocken Books, pp. $3^{-17}$. 
always cite other authors, her works, as historians and philosophers confirm, directly corresponded to the texts of Aristotle, Nietzsche, Bergson, Kant, Hegel, Benjamin, and Adorno, among many others. Moreover, it was Hannah Arendt who influenced the entire generation of critical theorists and feminists, in the 1980s-1990s. Thus, the primary task for Arendtian scholarship today could be putting her thought (back) in dialogue with other philosophers and political thinkers. Bernstein's book about Arendt rather reinforces her theoretical isolation.

\section{Возвращение к Ханне Арендт: как и почему?}

\section{Анастасия Кальк}

Аспирантка факультета политики Новой школы социальных исследований, сотрудница Центра трансрегиональных демократических исследований,

Адрес: 6 East 16th Street, New York City, New York, USA 100003

E-mail: akalk@newschool.edu

Рецензия: Richard J. Bernstein. Why Read Hannah Arendt Now? (Cambridge: Polity Press, 2018). 